\title{
Improving Properties of Concrete Replacing Cement and Natural Sand with Metakolin and Robo Sand
}

\author{
Jyoti Rani' ${ }^{1}$, Shashi Sharma ${ }^{2}$, Vikram Dhillon ${ }^{3}$ \\ 1M.Tech Scholar, ${ }^{2}$ Assistant Professor, ${ }^{3}$ Head of Department \\ 1,2,3 Department of Civil Engineering, JCDMCOE, Sirsa, Haryana, India
}

\begin{abstract}
How to cite this paper: Jyoti Rani | Shashi Sharma | Vikram Dhillon "Improving Properties of Concrete Replacing Cement and Natural Sand with Metakolin and Robo Sand" Published in International Journal of Trend in Scientific Research and Development

(ijtsrd), ISSN: 2456-

6470, Volume-3 |

Issue-4, June 2019, pp.849-850, URL: https://www.ijtsrd.c om/papers/ijtsrd23 944.pdf

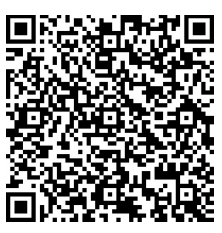

IITSRD23944
\end{abstract}

Copyright (C) 2019 by author(s) and International Journal of Trend in Scientific Research and Development Journal. This is an Open Access article distributed under the terms of the Creative Commons Attribution License (CC BY 4.0) (http://creativecommons.org/licenses/ by/4.0)

\section{INTRODUCTION}

Concrete isn't found in nature the manner in which we would discover aluminum, nickel or iron. Concrete is a composite structure material framed from joining bond with sand, smashed shake and water. Concrete is utilized more than some other man-made material on the planet. The qualities quality of cement relies on the properties of material and their joined activity. In the generation of bond $\mathrm{CO}_{2}$ gas emanation is increasingly, because of these outcomes in harm of characteristic climatic conditions. To lessen the utilization of bond halfway supplanting of concrete with some advantageous cementations materials like Metakaolin, fly-fiery remains, base powder, rice husk, GGBS and silica rage and so forth., are utilized in solid blend. Metakaolin is a dehydroxylated type of dirt mineral Kaolin. Stone having high level of kaolinite are known as china mud or kaolin was customarily utilized in assembling of porcelain for example earthenware material.

\section{Review of Literature}

L. Vyshnavi Sai, T.Yeswanth, M.Sambasiva Rao and Murthy et al. (2015) Experimentally located that impact of Metakaolin in concrete with partial substitute of cement for M30 grade concrete. Supplementary cementitious substances are finely floor stable substances which are used to update a part of cement in concrete mix. Metakaolin is a dehydroxylated aluminum silicate. From the recent research paintings the usage of Metakaolin it's far evident that it's far a completely powerful Pozzolanic fabric which enhances the strength parameters. due to this the compressive electricity was steadily increased up to $11 \%$ substitute of cement and for $20 \%, 30 \%$, forty $\%$ and $70 \%$ alternative of Metakaolin power is reduced.

Nikhil K. Kulkarni et al. (2015) evaluated the power of simple concrete with partial alternative of cement by way of Metakaolin and Fly ash. On this observe alternative of 13 cement with Metakaolin and Fly ash at zero\%, 5\%, 10\% and $15 \%$ and the compressive strength and flexural strength take a look at changed into performed for 7 and 28 days and as compared outcomes with regular concrete. Up to $10 \%$ substitute of cement with MK and Fly ash energy become expanded and for $15 \%$ decreased.

\section{Methodology}

In this study following test are carried out-

a. Compressive strength test

b. Split tensile strength test

c. Flexural strength test 
International Journal of Trend in Scientific Research and Development (IJTSRD) @ www.ijtsrd.com eISSN: 2456-6470

\section{Test RESULT}

1. Workability

The effect of Metakaolin and ROBO sand on fresh property concrete on workability shown in table

WORKABILITY OF M30 GRADE CONCRETE

\begin{tabular}{|c|c|c|}
\hline S.No & Mix Designation & Slump value \\
\hline 1 & Control Mix $(\mathrm{M})$ & $85 \mathrm{~mm}$ \\
\hline 2 & $0 \% \mathrm{MK}\left(\mathrm{M}_{1}\right)$ & $66 \mathrm{~mm}$ \\
\hline 3 & $6 \% \mathrm{MK}\left(\mathrm{M}_{2}\right)$ & $60 \mathrm{~mm}$ \\
\hline 4 & $12 \% \mathrm{MK}\left(\mathrm{M}_{3}\right)$ & $53 \mathrm{~mm}$ \\
\hline 5 & $18 \% \mathrm{MK}\left(\mathrm{M}_{4}\right)$ & $41 \mathrm{~mm}$ \\
\hline 6 & $24 \% \mathrm{MK}\left(\mathrm{M}_{5}\right)$ & $18 \mathrm{~mm}$ \\
\hline
\end{tabular}

It show the workability of concrete decrease as the perctanage of the Metakaolin will be increase.

1. Compressive strength COMPRESSIVE STRENGTH AT 7 DAYS, 28 DAYS AND 56DAYS

\begin{tabular}{|c|c|c|c|c|}
\hline SNo & $\begin{array}{c}\text { Mix } \\
\text { Designarum }\end{array}$ & $\begin{array}{l}\text { Compressive Strength } \\
\text { ut } 7 \mathrm{~d} y \mathrm{~s}\left(\mathrm{~N} / \mathrm{mm}^{2}\right)\end{array}$ & $\begin{array}{l}\text { Compressive } \\
\text { Strength at } 28 \text { dxys } \\
\left.\text { (N } \text { mmm }^{2}\right)\end{array}$ & $\begin{array}{l}\text { Compressive } \\
\text { Strength at } 55 \\
\text { days }\end{array}$ \\
\hline 1 & $\begin{array}{c}\text { Coctrol } 2 / 5 x \\
\text { (N) }\end{array}$ & 59.66 & 33.11 & 37.10 \\
\hline 2 & $070 \mathrm{MK}\left(\mathrm{M}_{\mathrm{l}}\right)$ & 20.56 & 33.92 & 3832 \\
\hline 3 & $6 \% \mathrm{ME}(\mathrm{OL})$ & 24.66 & 34.62 & 39.05 \\
\hline 4 & $12 \%$ ME $\left(\mathrm{M}_{4}\right)$ & 25.76 & 36.02 & 41.15 \\
\hline 5 & $18 \% \mathrm{ME}(\mathrm{M} / 4)$ & 23.26 & 34.13 & 38.50 \\
\hline 6 & $24 \%$ MK $(\mathrm{Mg})$ & 21.40 & 32.18 & 35.60 \\
\hline
\end{tabular}

Compressive strength at different percentage of Metakaolin shown in table. It shows that compressive strength will be increase as the percentage of Metakaolin will be increase up to $12 \%$. After this addition of Metakaolin compressive strength will not increase.

\section{Split Tensile strength}

The effect of Metakaolin and ROBO sand used in the present study on Split Tensile strength of concrete for M30 grade of different percentage $0 \%, 6 \%, 12 \%, 18 \%$ and $24 \%$ of Metakaolin shown in table

SPLIT TENSILE S T R E N G T H AT different days

\begin{tabular}{|c|c|c|c|c|}
\hline S.Ne & Max Desiguation & 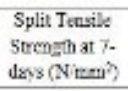 & 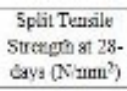 & 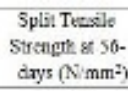 \\
\hline 1 & Controt Mix & 275 & 3.33 & 3.60 \\
\hline 2 & $0 A, \mathrm{MK}\left(\mathrm{ML}_{\mathrm{L}}\right)$ & 2.85 & 3.40 & 3.70 \\
\hline 3 & $6 \% \mathrm{MK}\left(\mathrm{M}_{2}\right)$ & 2.96 & 3.60 & 3.89 \\
\hline 4 & {$[2 \%, \mathrm{AK}(\mathrm{M})$} & 3.12 & 3.96 & 4.26 \\
\hline 5 & $185 \mathrm{MK}(\mathrm{M} \cdot)$ & 3.00 & 3.70 & 3.84 \\
\hline 6 & $24 \%, \mathrm{AE}\left(\mathrm{M}_{6}\right)$ & 2.93 & 3.62 & 3.68 \\
\hline
\end{tabular}

Split tensile strength also increase up to $12 \%$ of Metakaolin will be increase after that strength will be decreased.

\section{Flexural Strength}

The effect of Metakaolin and ROBO sand at various perctanage shown in table

FLEXURAL STRENGTH AT 7-DAYS and 28-DAYS AND 56

\begin{tabular}{|c|c|c|c|c|}
\hline \multicolumn{5}{|c|}{ DAYS } \\
\hline S.NO & Nix Designation & $\begin{array}{c}\text { Flexual } \\
\text { Strength at ?- } \\
\text { exys (Nimu) }\end{array}$ & $\begin{array}{c}\text { Flexural } \\
\text { Strength at } 28 \\
\text { days (N/mat) }\end{array}$ & $\begin{array}{l}\text { Flexual } \\
\text { Strength at } 56- \\
\text { days }\left(\mathrm{N} / \mathrm{mm}^{2}\right)\end{array}$ \\
\hline 1 & Control Mix (M) & 1.13 & 1.46 & 1.56 \\
\hline 2 & $03, \mathrm{MK}\left(\mathrm{M}_{1}\right)$ & 1.08 & 1.42 & 1.50 \\
\hline 3 & $6 \% \mathrm{MK}\left(\mathrm{Mr}_{2}\right)$ & 1.15 & 156 & 1.64 \\
\hline 4 & $12 \% \mathrm{MK}\left(\mathrm{M}_{3}\right)$ & 1.22 & 1.07 & 1.34 \\
\hline 5 & $18 \% \mathrm{MK}(\mathrm{ML})$ & 1.06 & 1.46 & 1.56 \\
\hline 5 & $24 \%, \mathrm{MK}\left(\mathrm{M}_{5}\right)$ & 0.99 & 1.32 & 1.42 \\
\hline
\end{tabular}

Flexural strength will be increase when Metakaolin perctanage increase up to $12 \%$ after it decrease.

\section{REFERENCES}

[1] Anbarasan and M.Venkatesan, "Effect of ROBO Sand on Strength Characteristics of Recycled Aggregate Concrete", International Journal of Engineering Research \& Technology, e ISSN: 2319-1163.

[2] A.V.S. Sai Kumar and B. Krishna Rao "A Study on Strength of Concrete with Partial Replacement of Cement with Quarry Dust and Metakaolin" International Journal of Innovative Research in Science, Vol.3, Issue 3, March 2014.

[3] Abid Nadeem, Johnny Y N Mok, Brian H Y Leung, Gary K W Tse, 2008, "Comparison of chloride permeability of metakaolin and fly ash concrete and mortars under elevated temperatures". 33rd conference on OUR WORLD IN CONCRETE \& STRUCTURES.

[4] Atul Dubey, Dr, R. Chandak, Prof. R.K. Yadav (August, 2012) - "Effect of blast furnace slag powder on compressive strength of concrete", International Journal of Scientific \& Engineering Research (IJSER), ISSN 2229-5518, Volume 3, Issue 8.

[5] B. B. Patil and P.D. Kumar, "Strength and Durability Properties of High Performance Concrete incorporating High Reactive Metakaolin", Vol. 2, Issue 3, may- June 2012, pp-1099-1104.

[6] Dojkov I, Stoyanov S, Ninov J, Petrov B, "On the consumption of lime by Metakaolin, Fly Ash and Kaolin in model systems" Journal of Chemical Technology and Metallurgy, 48, 2013, pp. 54-60.

[7] Dr. H. Sudarsana Rao, Dr. Vaishali. G. Ghorpade, Dr. H. M. Somasekharaiah, 2012, "Durability studies on metakaolin based glass fibre reinforced high performance concrete". IJASRT, Vol: 2(2), 204-211.

[8] Dr. P. Srinivasa rao, P. Sravana, Z. Abdul Rahim, Dr. T. Seshadri Sekhar, Dr. Ms. P. Aarathi, 2012, "Cracking behavior of metakaolin blended high strength concrete in flexure by using crimped steel fibers", Journal of Civil Engineering science9, Vol:1, 15-19. 